\title{
ВРАХУВАННЯ МАКРОКЛІМАТУ ПРИ ПРОЕКТУВАННІ ВИСОТНИХ БІОКЛІМАТИЧНИХ БУДІВЕЛЬ
}

\section{THE CONSIDERATION OF THE MACRO-CLIMATE IN THE DESIGN OF HIGH-RISE BIOCLIMATIC BUILDINGS}

\author{
Кривенко О.В., к.т.н., доцент (Київський національний \\ університет будівництва і архітектури, м. Київ)
}

\section{Krivenko O.V., Ph.d. in Engineering, Associate Professor (Kyiv National University of Building and Architectory, Kyiv)}

\begin{abstract}
Анотація. Для вирішення задач біокліматичної висотної архітектури важливим є врахування кліматичних впливів. У статті на основі узагальнення досвіду будівництва висотних будівель у районах зі складними кліматичними умовами та аналізу досліджень впливу макроклімату при проектуванні запропоновано структурну схему утворення макрокліматичного середовища 3 визначенням факторів впливу при формуванні висотної біокліматичної архітектури. Надано визначення макрокліматичного середовища як об'єднання природних та антропогенних чинників, щуо уточнюе макрокліматичну характеристику. Зроблено висновок, щчо дослідження макроклімату надає можливість при проектуванні враховувати комплекс кліматичних параметрів для визначення впливів на висотні біокліматичні будівлі.
\end{abstract}

Summary. Architectural, structural and technological solutions for high-rise buildings should provide a long-term service life under considerable loads and impacts, including climatic conditions. The basis of the decisions of the bioclimatic project for high-rise buildings is to determine the parameters of the bioclimate and to evaluate it. Bioclimatic assessment is an identification of positive and negative impacts of various climatic factors, which reveals the potential of the territory for rational use in construction. Climate assessment can be considered at three levels: macroclimate; mesoclimate (local climate), microclimate. The macro-climatic characteristics give the first idea of the climate background of the design, as well as the possibility of taking into account long-term forecasts of climate change. In the article the analysis of previous studies on the effect macroclimate in the design (the formation of general town planning requirements and modes of buildings in different types of weather).

The article states that the experience gained in constructing high-rise buildings in different climatic zones of the Earth requires analysis to extend previous research. This is especially true of climatic areas with complex climatic conditions, which significantly affect the design of high-rise buildings and their operation in extreme climatic conditions. The article discusses examples of high-rise buildings in more detail.

To solve the problems of bioclimatic high-altitude architecture, a structural scheme of formation of the macro-climatic environment is proposed, with the determination of 
the factors of positive and negative influence in the formation of high-altitude bioclimatic architecture.

Ключові слова: Макроклімат, біокліматичні висотні будівлі, кліматичні умови, тип погоди, антропогенні фактори.

Key words: macro-climate, bioclimatic high-rise buildings, climatic conditions, weather type, anthropogenic factors

Постановка проблеми. Біокліматичне будівництво набуває важливого значення при проектуванні висотних будівель. Архітектурні, конструктивні та технологічні рішення висотних будівель мають забезпечувати тривалий термін їх експлуатації при значних навантаженнях та впливах, у тому числі і кліматичних. Відомо, що у висотних та надвисотних будівлях вплив кліматичних факторів змінюється також із висотою будівлі: температура зовнішнього повітря знижується на $1{ }^{\circ} \mathrm{C}$ через кожні 150 м висоти, атмосферний тиск знижується на 1 гПа через кожні 8 метрів висоти, а швидкість вітру зростає із висотою) $[1,2]$.

В основі проектування біокліматичних будівель лежить принцип максимальної адаптації будівлі до оточуючого природного середовища, що дозволяє отримати архітектуру, що відповідає якостям природної екосистеми. Біокліматичне проектування будівлі має грунтуватися на аналізі багатьох аспектів клімату, їх добових та сезонних змін. $[2,3,4,5,7,8]$.

Основою рішень біокліматичного проектування висотних будівель $\epsilon$ визначення параметрів біоклімату, а також можливість його оцінки. Біокліматична оцінка - визначення позитивних та негативних впливів різних кліматичних факторів, що виявляє потенціал території для раціонального використання при будівництві $[2,6]$.

Оцінка клімату може розглядатись на трьох рівнях: макроклімат; мезоклімат (місцевий клімат), мікроклімат (рис.1.) [9,10,11].

Макрокліматичні характеристики дають перше уявлення щодо кліматичного фону проектування, а також можливість врахування при будівництві тривалих прогнозів зміни клімату. 3 точки зору розвитку біокліматичної архітектури висотних будівель корисним $є$ досвід будівництва висотних будівель у різних макрокліматичних умовах, що дає можливість формувати типологічні особливості проектних рішень висотних будівель для територій з однаковими фоновими показниками клімату.

Аналіз попередніх досліджень. Згідно 3 [10] клімат (від грецької klima - нахил) довгий час зв'язували з кутом (нахилом) падіння на Землю сонячних променів та висотою стояння Сонця, що залежить від широтного поясу Землі. При більш глибокому вивченні клімату Землі було встановлено, що на умови формування клімату впливають циркуляційні фактори (сонячна радіація, атмосферна циркуляція, обіг вологи), характер 
земної поверхні (рельєф,характер поверхні грунту, снігового та рослинного покрову), вплив моря [9,10,11,12].

Відповідно до існуючого кліматичного середовища відбувається адаптація людини до умов певного клімату. Це стосується як адаптації організму людини так і формування умов та укладу їі проживання.

Вплив клімату враховують при вирішенні багатьох архітектурно будівельних задач: вибір території забудови, планувальні та конструктивні рішення, розташування будівлі на місцевості з урахуванням орієнтації по сторонам світу, освітленості, інсоляції, аерації. [9,10,11,12].

Класифікація кліматів Землі проводиться як безпосередньо за кліматичними характеристиками (класифікація В. Кеппена), так i грунтується на особливостях загальної циркуляції атмосфери (класифікація Б. П. Алісова, рис.1.), чи відповідно до характеру географічних ландшафтів (класифікація Л. С. Берга). [10,11]

Відповідно із [9] у будівельній кліматології всі види клімату на Землі умовно поділяються на чотири типи: холодний, помірний, жаркий сухий та теплий вологий. У дослідженнях $[9,10]$ для кожного з типів клімату сформовано найбільш загальні містобудівні умови пов'язані з захистом людини від переохолодження, перегріву, захистом території від вітру, снігових чи пилових бур, від підвищеної вологості та зливів, забезпечення інсоляції території.

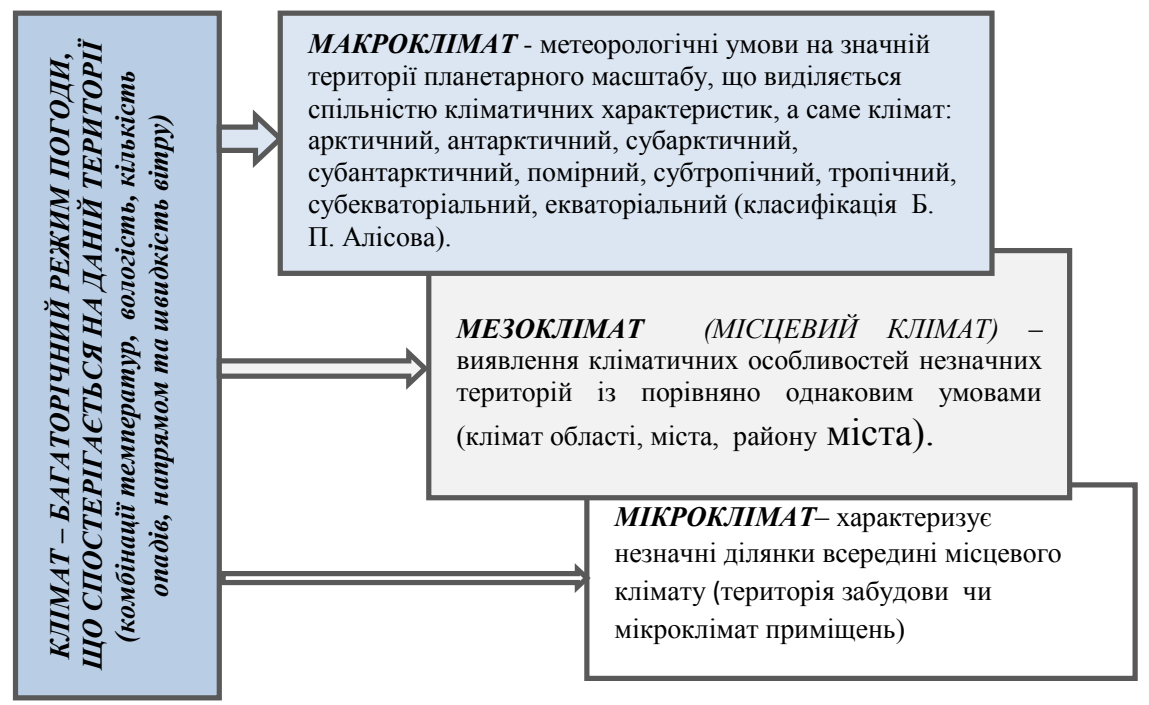

Рис.1. Клімат та рівні його оцінки 
Кліматичні фактори та ї взаємодія визначають погоду. кліматології в будівельній практиці відповідно із різноманітними сполученнями середньомісячних значень температури, вологості, швидкості вітру визначено сім типів погоди (спекотна суха, спекотна, тепла, комфортна, прохолодна, холодна, сурова). На основі класифікації типів погоди розроблені режими експлуатації будівель, де визначено загальні рекомендації щодо застосування архітектурних, конструктивних та інженерно - технічних засобів при проектуванні $[9,10]$.

Слід зазначити, що у $[9,10]$ автори виділяють основні характеристики режимів експлуатації будівель при різних типах погоди, в тому числі і для багатоповерхових будівель. Але питання проектування висотних та надвисотних будівель 3 урахуванням кліматичних умов та навантажень при їх експлуатації у зазначених дослідженнях не відображено. При цьому у дослідженнях відзначається важливість їх врахування [13].

Мета статті - визначити теоретично та практично обгрунтовані параметри щодо врахування макрокліматичних показників при проектуванні висотних біокліматичних будівель.

Постановка завдання - проаналізувати вплив макроклімату при проектуванні висотних будівель на основі узагальнення досвіду будівництва у районах зі складними кліматичними умовами та розробити структурну схему утворення макрокліматичного середовища 3 визначенням параметрів впливу при формуванні висотної біокліматичної архітектури.

Виклад основного матеріалу дослідження. Клімат - багаторічний режим погоди, що спостерігається на даній території. Макроклімат - тип клімату, що переважає на великих територіях. Макрокліматичний район характеризується відносно однорідними кліматичними характеристиками, відмінними від характеристик інших регіонів. Кліматичні умови макроклімату визначаються:кількістю сонячного випромінювання в залежності від широти, в різні моменти і пори року, а також близькістю моря, системою циркуляції атмосфери i висотою над рівнем моря $[9,10,11,12]$.

Як вже зазначалось, дослідження та досвід врахування параметрів різних типів клімату при проектуванні будівель мають значні напрацювання. Наприклад, розроблено архітектурно типологічні характеристики експлуатації будівель для різних типів погоди: спекотна суха, спекотна, тепла, комфортна, прохолодна, холодна, сувора.

Отриманий досвід будівництва висотних будівель у різних кліматичних поясах Землі потребує аналізу для розширення зазначеного вище досвіду. Особливо це стосується кліматичних районів із складними кліматичними умовами, що суттєво впливають на проектування висотних будівель та їх експлуатацію в екстремальних кліматичних умовах. 
Розглянемо більш детально приклади на основі зведених висотних будівель.

У жарких та сухих районах екваторіального, субекваторіального, тропічного клімату враховуються наступні фактори при проектуванні будівель: перегріте повітря $\left(35-45^{\circ} \mathrm{C}\right)$ при низькій вологості (24- 40\%), надлишок сонячної радіації, сильні пустельні вітри, що утворюють піщані бурі. Для захисту будівель від зазначених кліматичних факторів здавна в архітектурі застосовувались: затінення, аерація, повітронепроникненість та теплозахист приміщень, захист від пилових вітрів, засоби для охолодження приміщень. Сучасна висотна архітектура має вже значний досвід при проектуванні висотних будівель у таких кліматичних умовах в країнах Азії, Африки, Південної Америки. [9,10,11,12,14].

Наприклад, концепція офісної будівлі в Малайзії «EquatorTower» (380м, 80 поверхів) розроблена спеціально для сухого та жаркого екваторіального клімату. Конструкція хмарочоса включає додаткову систему захисту від сонячних променів. Висувний зовнішній шар - завіса 3 армованого склопластику, що розкривається, за допомогою тросової конструкції в жарку пору доби, здатна захистити приміщення будівлі від перегріву, без шкоди панорамним видам - ніби це погляд через тоноване скло. А із заходом сонця, вежа повинна "розкриватись" у всій своїй архітектурній красі [15]

У хмарочосі O-14, OAE, м. Дубай, район Бізнес Бей, з висотою 114м передбачено інноваційне рішення зовнішньої оболонки - залізобетонного екзоскелету товщиною 40 см 3 великим отворами. Різьблена тінь, яку дають стіни оболонки, допомагає утримувати приміщення від перегріву сонцем. Крім того, між білим фасадом i скляним ядром будівлі передбачений зазор шириною в один метр. При нагріванні у ньому виникають конвективні потоки повітря, що сприяють природній вентиляції всієї споруди, що знижує витрати енергії, забезпечуючи при цьому комфортні температури всередині будівлі .

При проектуванні в кліматичних районах 3 холодним та суворим типом погоди (арктичного, антарктичного, субарктичного та субантарктичного і наближеного до них помірного кліматичних районах) важливим є врахування небезпечної сумісної дії снігу, вітру та низьких температур, що може призвести до накопичення снігу - снігових заносів, обмерзання конструкцій, нерегульованого сходу снігу та криги 3 конструкцій будівлі. Для зниження небезпеки снігових заносів слід застосовувати аеродинамічні форми будівель, спеціальні рішення дахів 3 ухилом з завітреної сторони, будівництво на високих опорах. Крім того, слід застосовувати спеціальні об'ємно - планувальні рішення, які дозволяють знизити площу затінення, щоб унеможливити уповільнення танення снігу. [9,10,11,12,16]

При проектуванні найпівнічнішого на цей час хмарочосу світу «Лахта 
центр», м. Санкт Петербург (біля 1 тис. кілометрів до широти Північного полярного кола) передбачено комплекс засобів для вирішення зазначених кліматичних проблем. У «Лахта центрі» шпиль по структурі сітчастий, що $\epsilon$ пасивним засобом боротьби із обледенінням, тому що на сітці зменшується площа взаємодії металу та води. Коли на такій сітці все ж таки утворюється перший безпечний шар льоду, подається короткий електричний імпульс, який струшує його і не дозволяє льоду наростати далі. Крім того, буферні зони фасаду «Лахта центру» не дозволять переохолоджуватися зовнішньому склу, а внутрішнє засклення взагалі позбавлять від льоду. У сильні морози для стекол поза буферними зонами передбачено підігрів, що запобігає льодоутворенню. [17]

Потепління клімату відіграє певну роль в утворенні більш високого рівня моря та посилення штормів 3 небезпечними хвилями, ураганним вітром, проливними опадами. Особливої загрози зазнають кліматичні райони $з$ океанічним (морським) кліматом, який панує над океанами i поширюється на частини материків, що піддаються впливам морських повітряних мас. Наприклад, у жовтні 2012 року супершторм Сенді вразив райони мегаполісу Нью-Йорка, внаслідок чого постраждало понад 300000 будинків, 23000 підприємств, 17 відсотків загальної маси землі у місті було під водою, збитки сягнули 70 мільярдів доларів[18].

Отже, на сьогодні стає актуальним питанням забезпечення більшої стійкості будівель до змін в кліматі, а саме до здатності витримувати підвищення рівня моря, температур та інших кліматичних катастроф . Наприклад, будівельні фірми, такі як JDS Development Group, інвестують у стійку інфраструктуру - будівлі, які можуть протистояти паводкам та відключенню електропостачання при природних катастрофах. Прикладами висотних будівель, які здатні протидіяти руйнівній дії у води в світі є:

- «Monad Terrace», Майамі, США, арх.. Ж. Нувель, (рис. ) - нижній поверх будівлі піднятий на 3,5 метри; стійкі металеві та скляні опори, здатні протистояти урагану 5 категорії; потужна насосна система для видалення води з будівлі;

- «American Copper Buildings», м. Нью - Йорк, США - хмарочос JDSDevelopmentGroup стійкий до повеней, де передбачено засоби протидії стихії та іï наслідкам, а саме: облицювання водостійкими та водонепроникними матеріалами нижніх поверхів (стіни облицьовано міддю, каменем); окремі пасажирські ліфти, що не спускаються до рівня можливого підтоплення; паркова зона зі спеціально підібраними рослинами стійкими до соленої води, яка слугує захисним бар'єром для попередження попадання паводкової води в будівлю; дренажна насосна система навколо будівлі; спеціальні аварійні системи з енергозабезпечення розраховані на тривалий термін роботи, що розміщені на другому поверсі над можливою лінією затоплення [18]. 
Вирішення задач біокліматичної висотної архітектури потребує врахування комплексу факторів впливу макроклімату. (рис. 2) На сьогоднішньому етапі розвитку нашої цивілізації крім факторів природного впливу на клімат, важливим $є$ врахування антропогенних факторів впливу (щільність, склад населення; рівень урбанізації; політична ситуація в регіоні).

Антропогенний вплив грунтується на концепції системи «планетарних меж». Остання була запропонована у 2009 р. вченими екологами під керівництвом Йохана Рокстрема та Уіла Штеффена. Концепція планетарних меж сформована із списку планетарних меж у 9 областях (зміна клімату, закислення океану, виснаження озонового шару, біогеохімічні зміни, споживання прісної води, використання земель, втрата біорізноманіття, аерозольне та хімічне забруднення), що дозволяє визначити та кількісно оцінити експлуатаційні межі людської діяльності. Згідно досліджень Уіла Штеффена та інших, планета Земля вступила в новітню епоху - антропоген, коли людство стало основними агентами зміни системи Землі $[19,20,21]$.

Об'єднання природних та антропогенних факторів надає більш повну ніж макроклімат характеристику, що можна визначити як макрокліматичне середовище.

Слід зазначити, що природні та антропогенні фактори здійснюють як негативний так і позитивний вплив на формування макрокліматичного середовища (рис. 2).

Такий вплив при проектуванні варто розглядати 3 наступною черговістю:

1 Аналіз характерних типових факторів, що мають тривалу та прогнозовану характеристику дії. В більшій мірі це стосується природних факторів, що формують макрокліматичні показники та визначають кліматичний пояс.

2. Виявлення екстремальних впливів як природних (землетруси, шторми, цунамі, повені) так і антропогенних (можливі терористичні загрози, техногенні катастрофи).

3. Аналіз факторів можливих змін, що здатні призвести до зміни макрокліматичного середовища (перспективне зростання кількості та щільності населення, можливі зміни кліматичних показників, наприклад температурних, підняття рівня води, зміна характеру циркуляції атмосфери).

Висновки i перспективи подальших досліджень. Врахування параметрів різних типів клімату при проектуванні будівель мають значні напрацювання: для кожного з типів клімату сформовано найбільш загальні містобудівні умови, а також визначені основні характеристики режимів експлуатації будівель при різних типах погоди. Але особливості 


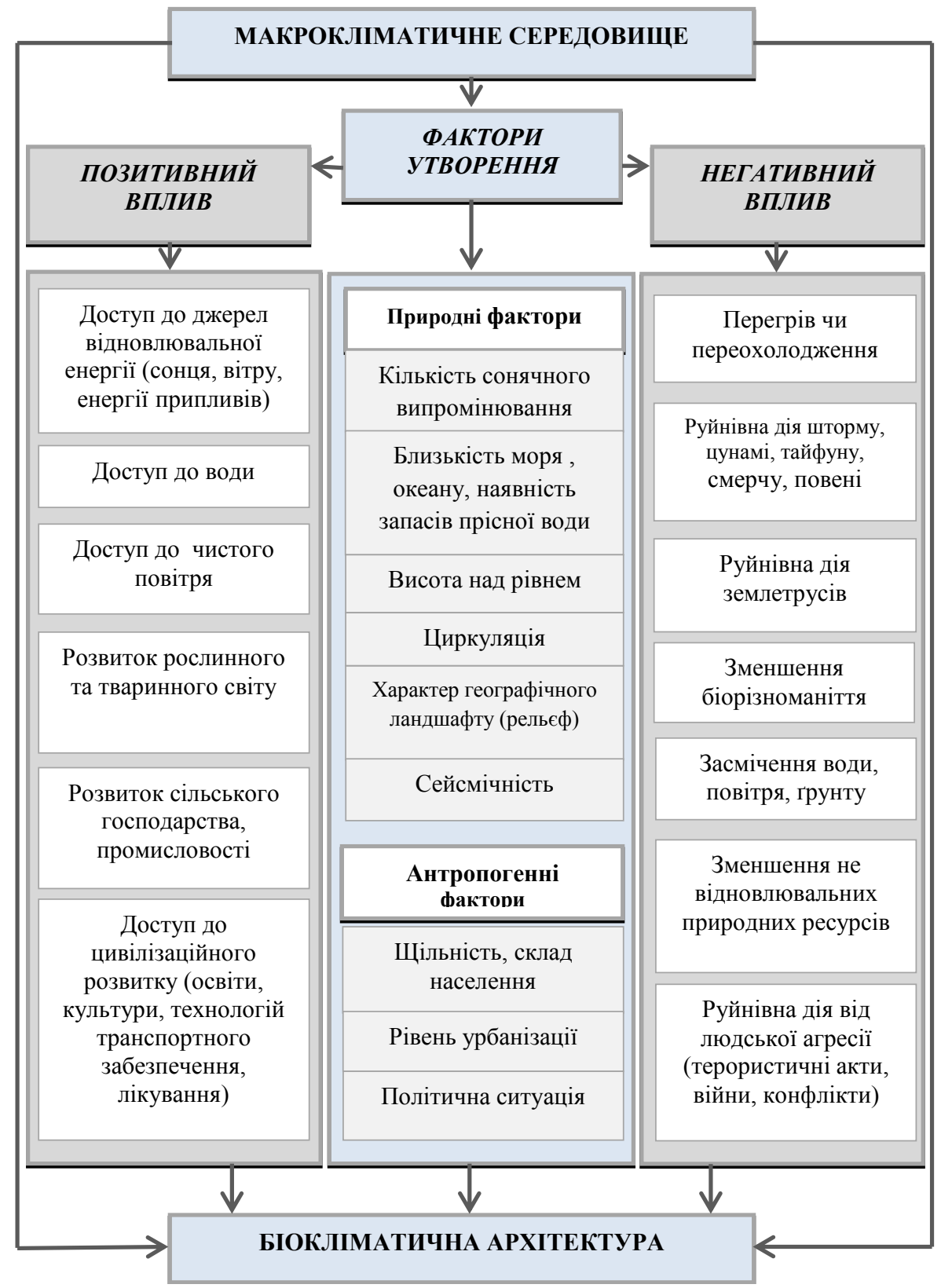

Рис.2. Структурна схема утворення макрокліматичного середовища 
проектування висотних та надвисотних будівель 3 урахуванням макрокліматичних умов та навантажень при їх експлуатації не досліджуються та не систематизуються. Хоча висотні та надвисотні будівлі зводяться сьогодні практично в усіх макрокліматичних умовах, що надає можливість для систематизації архітектурних, будівельних та технологічних засобів при їх проектуванні.

Дослідження в області макроклімату та аналіз їх результатів надає можливість при проектуванні враховувати комплекс кліматичних параметрів для визначення глобальних та тривалих впливів на висотні біокліматичні будівлі. Об'єднання природних та антропогенних факторів впливу представляє більш повну макрокліматичну характеристику, що можна визначити як макрокліматичне середовище.

\section{References}

1. Chesnokov A.G., Cheremkhina Ye.A. Proyektirovaniye ostekleniya vysotnykh zdaniy dlya slozhnykh klimaticheskikh rusloviy. M.: OAO «Institut stekla» (in Russion).

2. Krivenko O.V. Doslidzhennya vplyvu klimatychnykh parametriv pry proektuvanni bioklimatychnykh vysotnykh budivel' // tezy 9-oyi mizhnarodnoyi naukovo-praktychnoyi konferentsiyi «Enerhointehratsiya - 2019» (in Ukrainian).

3. Krivenko O.V. Bioklimatychna arkhitektura yak yavyshche v ekolohichniy arkhitekturi// Enerhoefektyvnist' $\mathrm{v}$ budivnytstvi ta arkhitekturi, vyp.4, KNUBA, K.:2013, s.155-160 (in Ukrainian).

4. Hyde, Richard. Bioclimatic Housing. Innovative Designs for Warm Climates// Richard Hyde.- Paperback.- December 2007.-400 p.

5. Olgyay, V. (1963). Design with climate bioclimatic approach and architectural. Princeton: Princeton University Press.

6. Krivenko O.V. Opredeleniye parametrov bioklimata territorii zastroyki pri reshenii zadach bioklimaticheskoy arkhitektury gorodov //Construction of optimized energy potential, вип..2, Czestochowa university of technology:, Czestochowa : 2014, p. 23-29 (in Russion).

7. Ken Yeang, Lucy Bullivant. Eco Skyscrapers II , The Images Publishing Group, 01.01.2011

Ecological basis for Architectural Design/ Ken Yeang.- New York: McGraw Hill Publication, 1995.

9. Tymofyeyev M.V., Serheychuk O.V., Shamrina H.V. Kompleksna otsinka klimatychnykh umov zhytlovoyi zabudovy.-K.,KNUBA, 2015. - 128s (in Ukrainian).

10. Mikheyev A.P., Beregovoy A.M., Petryanina L.N. Proyektirovaniye zdaniy i zastroyki naselennykh mest s uchetom klimata i energosberezheniya. - M.: Izdatel'stvo ASV, 2002. - 192 s. (in Russion).

11. Kupriyanov V.N.: Stroitel'naya klimatologiya i fizika sredy: Uchebnoye posobiye. - Kazan': KGASU, 2007. - 114 s. $542 \mathrm{p}$.

12. Markus T. A. and Morris E.N. Buildings, Climate and Energy, Pitman 1980.

13. Robert Goodwin Context, Climate, Culture - Investigating Place in Tall Buiding Design.: CTBUH Research Paper, 2015/ 257 p. 
14. Rimsha A.N. Gradostroitel'stvo v usloviyakh zharkogo klimata: Uchebnik dlya vuzov.-M.: Stroyizdat, 1979.-312 s

15. Hyde, Richard. 2007. Bioclimatic Housing. Innovative Designs for Warm Climates/ Richard Hyde.- Paperback. 400 p.

16.Berezovskiy B.I., Vas'kovs'kiy A.P. Proyektirovaniye i stroitel'stvo zdaniy v usloviyakh surovogo klimata i vechnomerzlykh gruntov. Ucheb. Posobiye dlya vuzov. L., Stroizdat, 1977, $232 \mathrm{~s}$.

17. Online resource https://lakhta.center/en/

18. Laurn J. Young. Building A Flood-Proof Skysraper Resilient To Climate Change. Off - Air, 2017

19. Yeliseyev A.V. «Izmeneniye klimata i kharakteristik nazemnykh ekosistem pri nalichii antropogennogo i yestestvennogo vozdeystviya». Avtoreferat doktora fiz. - mat. nauk 25.09.29 - Fizika atmosfery i gidrosfery, M. - 2010, 48c.

20. Steffen W et al., (2015): Planetary boundaries: Guiding human development on a changing planet. In: Science 349, No. 6254, pp. 12861287, doi:10.1126/science. 1259855

21. Steffen W, Grinevald J, Crutzen P and McNeill J (2011) "The Anthropocene: conceptual and historical perspectives" Philosophical Transactions of the Royal Society A369(1938): 842-867. doi:10.1098/rsta.2010.0327

\section{Список використаної літератури}

1. Чесноков А.Г., Черемхина Е.А. Проектирование остекления высотных зданий для сложных климатических условий. М.: ОАО «Институт стекла»// електроний ресурс https://docplayer.ru/31993500-Proektirovanie-ostekleniya-vysotnyhzdaniy-dlya-slozhnyh-klimaticheskih-usloviy-chesnokov-a-g-cheremhina-e-a-oaoinstitut-stekla-moskva.html

2. Кривенко О.В. Дослідження впливу кліматичних параметрів при проектуванні біокліматичних висотних будівель // тези 9-ої міжнародної науковопрактичної конференції «Енергоінтеграція - 2019»

3. Кривенко О.В. Біокліматична архітектура як явище в екологічній архітектурі// Енергоефективність в будівництві та архітектурі, вип..4, КНУБА, К.:2013, c.155-160

4. Hyde, Richard. Bioclimatic Housing. Innovative Designs for Warm Climates// Richard Hyde.- Paperback.- December 2007.-400 p.

5. Olgyay, V. (1963). Design with climate bioclimatic approach and architectural. Princeton: Princeton University Press.

6. Кривенко О.В. Определение параметров биоклимата территории застройки при решении задач биоклиматической архитектуры городов//Construction of optimized energy potential, вип..2, Czestochowa university of technology:, Czestochowa : 2014, p. 23-29

7. Ken Yeang, Lucy Bullivant. Eco Skyscrapers II , The Images Publishing Group, 01.01.2011

8. Yeang, Ken. Designing with Nature: The Ecological basis for Architectural Design/ Ken Yeang.- New York: McGraw Hill Publication, 1995.

9. Тимофєєв М.В., Сергейчук О.В., Шамріна Г.В. Комплексна оцінка кліматичних умов житлової забудови.-К.,КНУБА, 2015. $-128 \mathrm{c}$.

10. Михеев А.П., Береговой А.М., Петрянина Л.Н. Проектирование зданий и застройки населенных мест с учетом климата и энергосбережения. - М.: 
Издательство АСВ, 2002. - 192 с.

11. Куприянов В.Н.: Строительная климатология и физика среды: Учебное пособие. - Казань:КГАСУ, 2007. - 114 с.

12. Markus T. A. and Morris E.N. Buildings, Climate and Energy, Pitman 1980. $542 \mathrm{p}$.

13. Robert Goodwin Context, Climate, Culture - Investigating Place in Tall Buiding Design.: CTBUH Research Paper, 2015/ 257 p.

14. Римша А.Н. Градостроительство в условиях жаркого климата: Учебник для вузов.- М.: Стройиздат, 1979.-312 с

15. Інтернет ресурс https://rex-ny.com/project/equator-tower/

16. Березовский Б.И., Васьковський А.П. Проектирование и строительство зданий в условиях сурового климата и вечномерзлых грунтов. Учеб. Пособие для вузов. Л., Строиздат, 1977, 232 с.

17. Інтернет ресурс https://lakhta.center/ru/

18. Laurn J. Young. Building A Flood-Proof Skysraper Resilient To Climate Change. Off - Air, 2017

19. Елисеев Алексей Викторович «Изменение климата и характеристик наземных экосистем при наличии антропогенного и естественного воздействия». Автореферат доктора физ. - мат. наук 25.09.29 - Физика атмосферы и гидросферы, М. - 2010, 48c.

20. Steffen W et al., (2015): Planetary boundaries: Guiding human development on a changing planet. In: Science 349, No. 6254, pp. 12861287, doi:10.1126/science. 1259855

21. Steffen W, Grinevald J, Crutzen P and McNeill J (2011) "The Anthropocene: conceptual and historical perspectives" Philosophical Transactions of the Royal Society A369(1938): 842-867. doi:10.1098/rsta.2010.0327 